\title{
The Effect of Authentic Learning Approach in Social Studies Teaching on the Academic Success
}

\author{
Fitnat Gürgil \\ Social Studies Education Department, Gazi Faculty of Education, Gazi University, Ankara, Turkey
}

Copyright $(2018$ by authors, all rights reserved. Authors agree that this article remains permanently open access under the terms of the Creative Commons Attribution License 4.0 International License

\begin{abstract}
The purpose of this study is to determine the impact of authentic learning activities organized within the scope of the social studies course of 5th grade students on the academic success. Quasi-experimental design which is one of the quantitative research methods was used in the research. The study was carried out in the academic year of 2017-2018 in schools that represent three different socioeconomic statuses in Ankara province. 62 students from Çankaya Province; 61 students from Yenimahalle Province and 61 students from Altındağ Province; a total of 184 students participated in the study. Academic achievement test developed by a researcher was used as a data collection tool in the study. According to the results, the academic success of experimental groups where authentic learning activities were used was found to be higher than the academic success of the control groups where the available programs were used. Again, in the groups where authentic learning was applied, it was found out that the girls were more successful than the boys. It was also found out that authentic learning activities increase success in all classes with socioeconomic status.
\end{abstract}

Keywords Authentic Learning, Social Studies, Academic Achievement

\section{Introduction}

What is as important as learning something new in a changing and transforming World order is that things learned should be meaningful and permanent. Many different theories, models, strategies and techniques have been developed in education for permanent and meaningful learning. Authentic learning is one of these insights.

The French origin word, "authentique", which is introduced to Turkish means "having the characteristics that have existed since ancient times" according to the Turkish Language Society [1] Great Dictionary. In the terminology of education, use of the word 'authentic' is quite different. The term of authentic used in the area of education has the meaning of 'close to reality, reflecting reality'. Just to make definition with regards to the learning-teaching process, "authentic learning can be defined as education given in an environment which is very similar to reality or in the real environment" (p.291) [2]. Authentic learning insight is often based on a constructivist approach. Because it both emphasizes learning by experience, problem solving, and associating to everyday life. In the authentic learning insight, students are expected to be active and teachers are expected to guide students by planning the learning process just like the constructivist approach.

Authentic learning is accepted as a learning insight that is beneficial for the learning process of students in many aspects. We can put these benefits in order as follows [3, 4, 5, 6, 7, 8, 9]:

- Contributes to the development of high-level thinking skills.

- $\quad$ Provides deep, meaningful and permanent learning.

- $\quad$ Provides a link between learned life and real life.

- Increases students' success.

- $\quad$ Provides students with social support.

- Ensures finding solutions to problems.

- Improves the sense of responsibility.

- $\quad$ Provides the synthesis of information.

- Increases attendance to lessons

- It is based on research and query.

- Shows that events are multidimensional.

- Brings in an interdisciplinary perspective.

Authentic learning aims to bring students in the knowledge, skills and values that are necessary for them in school environment [10]. The goal of authentic learning is to carry everyday life into the school environment. However, this environment must be as complicated and multidimensional as everyday life [7, 8, 11, 12]. For students, it is very important to comprehend that the problems they confront with have different dimensions, just like in real life. Because the solutions found by the students for these problems are expected to be multidimensional as well. "What is essential for students in 
authentic learning is to be able to find solutions to current problems by transferring what they have learned into real life" (p. 13) [12]. A wide variety of roles should be given to students in authentic learning activities. Thanks to these roles, which represent different dimensions of activities, students can see different perspectives, they can understand reasons of problems more easily and find more realistic solutions to them.

Horzum and Bektash [11] indicate that activities and tasks should be both individual and group homework. İneç \& Akpınar [7], on the other hand, express that teachers are masters and students are apprentices in this learning insight. In this learning insight, teachers are guides of students. Herrington \& Herrington [13] suggests that the teacher should manage the learning process as a coach. Knoblock [5] notes that authentic learning contributes considerably to students in synthesizing information, generalizing information more easily, and in hypothesizing. The task of teachers is to prepare activities, tasks and evaluations suitable for authentic learning in appropriate learning environments. Authentic learning is flexible, and changes can be made within the process. The process can be enriched with new tasks and activities.

Authentic learning is one of the areas of study attracting more and more attention, although it is not a new insight $[9$, 12]. As literature is examined it is seen that there have been done researches in maths $[14,15]$; Turkish [16, 17]; history [18]; visual arts [19]; science [12]; English [20]; life studies [8] and social studies courses [7, 21, 22, 23, 24, 25] based on authentic learning. Also in some of the researches involve authentic learning activities achieved during teacher training period [2, 26, 27, 28, 29]. İneç [25] in his research states that authentic learning provides benefit at materializing abstract subjects. Herrington, Parker \& Boase-Jelinek [30] attracts attention that authentic learning is important in terms of presenting students the opportunity of real life duties as well as high level thinking and doing an act. On the other hand Akça \& Ata [18] says authentic learning should be applied more at point of overcoming rote learning understanding. It is also seen that conducted studies are intensely suitable to qualitative research paradigm. In this research, quantitative research approach has been adopted. Unlike other studies, this study was carried out simultaneously in 3 different secondary schools with different socioeconomic status. In this study, it is aimed to determine the impact of authentic learning activities on learning of students with different socioeconomic status.

Computer technology was used in the authentic learning activities organized in this study. Authentic activities were organized with WebQuest applications in the field of 'Production, Distribution and Consumption' learning selected within the scope of 5 th grade social studies course. Through such an application, a teaching tool, which is becoming more and more widespread in everyday life, was used and it was also desired to utilize the tasks that are compatible with the individual and group activities of the WebQuest. Various scenarios were created in the prepared WebQuest unit and the topic was explained over a fiction. The students were given the opportunity to conduct their research by being given the tasks in the form of directives. There are some problems in using internet in the education environment. The information that students receive from internet sites that are not suitable for research and do not contain realistic information cause intense criticism. In WebQuest applications used in educational environments, the teacher presents all the web pages that students will visit to their students in the WebQuest environment. This way, the problem of visiting harmful and inappropriate web pages goes away. This is another reason for using WebQuest in this study.

The aim of this research is to determine the effect of authentic learning activities prepared within the scope of the 5th grade social studies course 'Production, Distribution and Consumption' on the learning of students. In this context, the sub-goals of the research are as follows:

Academic achievement test results of experimental group and control group students;

a). Does it varies by groups (experimental-control)?

b). Does it varies by measurements (pretest-posttest)?

c). Does it varies by common effects of group*measurement factors?

d). Does it varies by gender?

e). Does it varies by the socioeconomic status of the schools?

\section{Materials and Methods}

\subsection{Model of Research}

Pretest-posttest control group experimental design from semi-trial models were used in the research. According to Çepni (p.123) [31] and Karasar (p. 99) [32], the semi-trial models come after the real experimental methods in terms of scientific value. In cases, where the classes are predetermined independently of the researcher (central examinations, school administrators, etc.), quasi-experimental design from experimental designs is applied. According to Çepni (p.123) [31] in such patterns, one of the classes in the school is determined as an experimental group and the other class is determined as a control group. In this research, quasi-experimental model was applied because the classes were prepared before the research. One of the existing classes in schools was chosen as an experimental, and the other was chosen as the control group randomly.

\subsection{Study Group}

While the study group was determined, 3 different secondary schools in Ankara were detected. These schools 
were determined in a way that they are the high (a school from the Çankaya district), medium (a school from Yenimahalle district) and low (a school from the Altındağ district) levels in terms of socioeconomic status, according to the data from Turkey Statistical Institute. The experimental groups in three different schools were applied the authentic learning activities of social studies course for 18 course hours. The program, which is also available to the control groups of three different schools, was taught with the same learning area for 18 course hours. The distribution of the participants in the study group in terms of variables is given in table 1.

Table 1. The distribution of the study group students in terms of variables

\begin{tabular}{|c|c|c|c|}
\hline Variable & Type of Variable & $\mathrm{f}$ & $\%$ \\
\hline \multirow{3}{*}{ Gender } & Females & 94 & 51.1 \\
\cline { 2 - 4 } & Males & 90 & 48.9 \\
\cline { 2 - 4 } & Total & 184 & 100 \\
\hline \multirow{4}{*}{ Group } & Experimental & 92 & 50 \\
\cline { 2 - 4 } & Control & 92 & 50 \\
\cline { 2 - 4 } & Total & 184 & 100 \\
\hline \multirow{3}{*}{$\begin{array}{c}\text { Socioeconomic } \\
\text { Status }\end{array}$} & Low & 61 & 33.2 \\
\cline { 2 - 4 } & Medium & 61 & 33.2 \\
\cline { 2 - 4 } & High & 62 & 33.7 \\
\cline { 2 - 4 } & Total & 184 & 100 \\
\hline
\end{tabular}

The reason for conducting this research in three different socioeconomic groups is to see the effect of the socioeconomic status on results. For this reason, the same experimental procedures were carried out in schools in different districts representing low, medium and high socioeconomic income groups. All processes and measuring tools in the experimental and control groups are identical. The applications were done and the data were collected simultaneously.

\subsection{Data Collection Tool}

The achievement test prepared within the scope of the social studies course of 5 th grade students started with literature review including "Production Distribution and Consumption" unit of "What we produce". A draft achievement test consisting of 40 questions was prepared by reviewing the literature. The prepared draft achievement test was submitted to the opinion of two lecturers studying in the field of social studies and a lecturer studying in the field of assessment and evaluation and two teachers. The required adjustments were made in line with the feedbacks of the experts. Accordingly, 4 questions were removed from the test and 3 questions were adjusted. The draft achievement test was applied to 213 students studying in three different schools that display low, medium and high socioeconomic characteristics. In the item analysis of the achievement test, the difficulty and discriminability indices of each item were calculated. Six unsuitable items were removed from the achievement test. 30 items with a KR 20 reliability coefficient of .83 were included in the achievement test.

\subsection{Data Analysis}

SPSS.21 package program was used in the analysis of the obtained data. For the analysis of the first three sub-problems of the study, Mixed Between-Within ANOVA test was performed. The t-test was used for the related samples to see differences in pretest and posttest scores of the experimental and control groups. Mixed Between-Within variance analysis was conducted to determine whether authentic learning activities vary by the variable of gender. Mixed Between-Within variance analysis was also conducted to test whether the effect of authentic learning activities on academic achievement varies by socioeconomic status. Significance level is taken as 0.5 .

\section{Findings}

In this study, it is aimed to investigate the effect of authentic learning activities prepared within the scope of social studies learning "Production, Distribution and Consumption" on the learning of secondary school students. Three experimental groups and three control groups were included in the study. The measurement tool prepared in both groups was applied as pretest and posttest. The findings are presented below.

\section{a). Authentic Learning Activities and Effects of the Course Taught in Line With the Available Programs on the Academic Achievement}

In order to seek an answer to the first three research questions of this study, Mixed Between-Within ANOVA was conducted. That is, the effect of the social studies course taught in line with the authentic learning (AL) activities and the social studies course taught in line with the available programs (AP) on the academic achievement of students were examined according to the group, time and time-group based interaction. In these analyzes, while the academic achievements of students in the social studies course constitute dependent variable, they represent two different time periods, which is before and after applying time variables. Group variable consists of the experimental group where course is taught in line with the authentic learning (AL) activities and the control group where the course is taught in line with the available programs (AP). The scores and standard deviations of the students in the experimental and control groups before and after the application are given in Table 2. 
Table 2. Average and standard deviation values for students' achievement scores

\begin{tabular}{|c|c|c|c|}
\hline Period of Time & $n$ & $M$ & $S D$ \\
\hline Pre- Test (AL) & 92 & 10.08 & 1.43 \\
\hline Pre- Test (AP) & 92 & 10.05 & 1.43 \\
\hline Post- Test (AL) & 92 & 23.54 & 3.19 \\
\hline Post- Test (AP) & 92 & 15.58 & 2.61 \\
\hline
\end{tabular}

Table 2 shows that there is a significant interaction between time and the two different methods applied, Wilks' Lambda $=.31, \mathrm{~F}(1,182)=415.58, \mathrm{p}<.05$, partial eta square $(\eta 2)=70$. Wilkins' Lambda $=.07, F(1,182)=$ 2373.56, $\mathrm{p}<.05, \eta 2=.93$. The main effect showing the change in academic achievement over time was also observed to be statistically significant, $F(1,182)=207.99$, $\mathrm{p}<.05, \eta 2=.53$. In addition, the main effect comparing the groups (applied method) was also observed to be significant $(\mathrm{F}(1,182)=207.99, \mathrm{p}<.05, \eta 2=.53$. These findings show that the effects of two different applications on the academic achievement of students are different. That is to say, considering the pretest and posttest scores of both groups, it is seen that in the beginning, both groups had almost the same success level, but after the application, the increase in the experimental group is higher than the increase in the control group. The effect size of difference between the groups indicates that 53\% of the total variance in academic achievement is explained by the method applied.

Table 3. Findings obtained for academic achievement from the mixed between within variance analysis

\begin{tabular}{|c|c|c|c|c|}
\hline & $\begin{array}{c}\text { Wilks, } \\
\text { Lambda }\end{array}$ & F(1,182) & $p$ & $\eta^{2}$ \\
\hline $\begin{array}{c}\text { Time-Group } \\
\text { interaction }\end{array}$ & .31 & 415.58 & $.000 *$ & .70 \\
\hline $\begin{array}{c}\text { Time (pre-test, } \\
\text { post-test) }\end{array}$ & .07 & 2373.56 & $.000 *$ & .93 \\
\hline $\begin{array}{c}\text { Group (AL, } \\
\text { AP) }\end{array}$ & 207.99 & $.000 *$ & .53 \\
\hline
\end{tabular}

*There is a statistically significant difference at the level of $\mathrm{p}<.05$.

In order to examine the effect of method and time independent variables on academic achievement separately and in more detail, syntax codes were expanded and paired comparisons were made with t-test for related samples and t-test for dependent samples. In these comparisons, Bonferroni correction was applied in order to reduce the probability of making Type I mistakes that could result from the division of the sample.

The difference between the pretest scores of the experimental and control groups is not statistically significant $(\mathrm{p}=.918, \eta 2=.00)$ according to the t-test results for the independent samples that are made to compare the pre and post test scores between the experimental and control groups (Table 4). However, the difference between the posttest scores of the groups is statistically significant $(p=.000, \eta 2=.65)$. These findings show that the posttest scores of the students in the group where the authentic learning (AL) activities are applied are higher than the achievement scores of the group where in the available programs (AP) is applied and the difference between the averages after practices is quite big [33].

Table 4. Comparison of academic achievement of groups in pre-test and post-test

\begin{tabular}{|c|c|c|c|c|}
\hline $\begin{array}{c}\text { Period of } \\
\text { Time }\end{array}$ & $\begin{array}{c}\text { Difference Btw } \\
\text { Averages }\end{array}$ & $\begin{array}{c}\text { Standard } \\
\text { mistake }\end{array}$ & $p^{\prime}$ & $\begin{array}{c}\text { Partial Eta } \\
\text { Square }\end{array}$ \\
\hline $\begin{array}{c}\text { 1.Pre-test } \\
\text { (AL and } \\
\text { AP) }\end{array}$ & .022 & .21 & .918 & .00 \\
\hline $\begin{array}{c}\text { 2.Post-test } \\
\text { (AL and } \\
\text { AP) }\end{array}$ & $7.97^{*}$ & .43 & .000 & .65 \\
\hline
\end{tabular}

* The difference between the averages is statistically significant. 'Bonferroni adjustment was made for comparisons.

Table 5. Paired comparison made with intra group pre-test and post-test scores

\begin{tabular}{|c|c|c|c|c|}
\hline Group & $\begin{array}{c}\text { Differences btw } \\
\text { averages } \\
\text { (pre test-post } \\
\text { test) }\end{array}$ & $\begin{array}{c}\text { Standard } \\
\text { Mistake }\end{array}$ & $P^{\prime}$ & $\begin{array}{c}\text { Partial } \\
\text { Eta } \\
\text { Square }\end{array}$ \\
\hline $\begin{array}{c}\text { AP (pretest } \\
\text { and posttest) }\end{array}$ & $-5.52^{*}$ & .28 & .000 & .69 \\
\hline $\begin{array}{c}\text { AL (pre-test } \\
\text { and posttest) }\end{array}$ & $-13.47^{*}$ & .28 & .000 & .93 \\
\hline
\end{tabular}

* The difference between the averages is statistically significant.

'Bonferroni adjustment was made for comparisons.

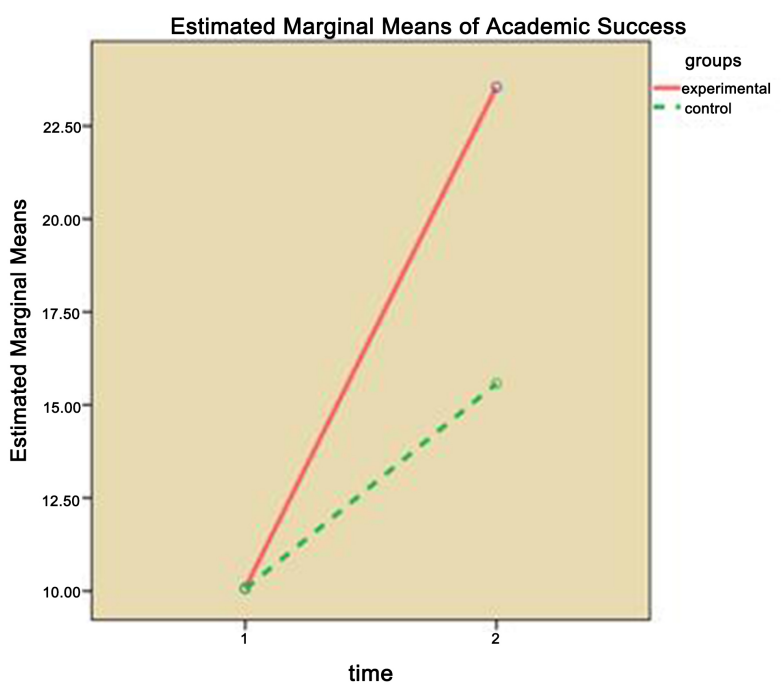

Figure 1. Change in the academic achievement of the students in the experimental and control groups over time.

Finally, the findings (Table 5) obtained as a result of the t-test for the related samples made in order to compare pre-test and post-test scores of experimental and control groups within itself, show that the success scores in the experimental group $(p=.000, \eta 2=93)$ and the control group $(p=.000, \eta 2=93), \eta 2=69)$ increased statistically and significantly. Considering the effect sizes calculated by 
the partial eta square, it can be said that the contribution of the authentic learning (AL) activities applied in the experimental group to increasing the academic achievement is higher than the contribution of the available programs (AP) applied to the control group. The diagram showing the effect of the applied methods on the academic achievement of the experimental and control groups is given in Figure 1.

\section{b). Effects of the Course taught in line with the Authentic Learning Activities by Gender}

The above findings have shown that the social studies course that is given according to the authentic learning activities is more effective on the academic success than the available programs. The fourth research problem of the study focuses on whether this effect of the teaching method based on authentic learning activities varies by gender. In order to test this research question, mixed between-within variance analysis was performed. In this analysis, while the success scores of the experimental group constitute the dependent variable, time constitutes the first independent variable which expresses the pretest and posttest time periods and the gender constitutes the second independent variable. Table 6 shows the academic success scores and standard deviations that male and female students from the experimental group took from pre- and post-tests.

Table 6. The mean and standard deviation values for the success scores of male and female students in the experimental group

\begin{tabular}{|c|c|c|c|}
\hline Period of Time & $n$ & $M$ & $S D$ \\
\hline Pre-test(Girls) & 46 & 10.22 & 1.50 \\
\hline Pre-test(Boys) & 46 & 9.93 & 1.37 \\
\hline Post-test(Girls) & 46 & 24.43 & 2.66 \\
\hline Post-test(Boys) & 46 & 22.65 & 3.45 \\
\hline
\end{tabular}

Table 7. Findings obtained from mixed between-within variance analysis by gender

\begin{tabular}{|c|c|c|c|c|}
\hline & $\begin{array}{c}\text { Wilks' } \\
\text { Lambda }\end{array}$ & $\mathrm{F}(1,182)$ & $\mathrm{p}$ & $\eta 2$ \\
\hline $\begin{array}{c}\text { Time-Gender } \\
\text { interaction }\end{array}$ & .93 & 6.57 & $.012^{*}$ & .068 \\
\hline $\begin{array}{c}\text { Time (pre-test, } \\
\text { post-test) }\end{array}$ & .04 & 2117.67 & $.000^{*}$ & .959 \\
\hline $\begin{array}{c}\text { Gender (girls, } \\
\text { boys) }\end{array}$ & 6.48 & $.013^{*}$ & .067 \\
\hline
\end{tabular}

*There is a statistically significant difference at the level of $\mathrm{p}<.05$.

Findings obtained (Table 7) show that there is a statistically significant interaction between gender and time, Wilks' Lambda $=.93, \mathrm{~F}(1,90)=6.57, \mathrm{p}=.000, \eta 2$ $=.068$. Similarly, the main effect making comparison by gender was found to be significant, $F(1,190)=6.47, p$ $=.013, \eta 2=.067$. This shows that the gender variable accounts for $6.7 \%$ of the total variance of the academic success scores. According to Cohen's [33] criteria, both effect sizes are moderate. Since the change in the groups is in the same direction, the main effect which makes a comparison according to the time was examined and it was seen that this effect is significant as well, Wilks' Lambda $=.04, \mathrm{~F}(1,90)=2117.67, \mathrm{p}=.000, \eta 2=.96$. The effect size of the change over time is quite high [33].

Table 8. Comparison of academic achievements in pre-test and post-test

\begin{tabular}{|c|c|c|c|c|}
\hline $\begin{array}{c}\text { Period of } \\
\text { Time }\end{array}$ & $\begin{array}{c}\text { Differences btw } \\
\text { averages } \\
\text { (Girls-Boys) }\end{array}$ & $\begin{array}{c}\text { Standard } \\
\text { error }\end{array}$ & $p^{\prime}$ & $\begin{array}{c}\text { Partial } \\
\text { Eta } \\
\text { Square }\end{array}$ \\
\hline $\begin{array}{c}\text { 1.Pre-Test } \\
\text { (girls and } \\
\text { boys) }\end{array}$ & .283 & .29 & .347 & .01 \\
\hline $\begin{array}{c}\text { 2.Post-test } \\
\text { (girls and } \\
\text { boys) }\end{array}$ & $1.783^{*}$ & .64 & .007 & .08 \\
\hline
\end{tabular}

* The difference between the averages is statistically significant.

'Bonferroni adjustment was made for comparisons.

Paired comparisons were conducted to examine the effect of gender and time variables on academic success in more detail. In these comparisons, Bonferroni adjustment was applied to reduce the potential of Type 1 error. Firstly, pretest and posttest scores between girls and boys were compared with t-test on independent samples. Findings (Table 8) obtained show that there is a statistically significant difference in posttest scores between girls and boys $(p=.007, \eta 2=.08)$, while there is no statistically significant difference in pre-test scores between girls and boys $(\mathrm{p}=.347, \eta 2=.010)$. In other words, while both groups had similar scores in the pre-test, in the posttest girls were found to be more successful than boys despite the increase in success of both groups. Moreover, the effect size of the difference between the academic achievements in the post-tests was found to be moderate.

Table 9. Paired comparison made with intra-group pre-test and post-test scores

\begin{tabular}{|c|c|c|c|c|}
\hline Group & $\begin{array}{c}\text { Differences } \\
\text { btw averages } \\
\text { (pre test-post } \\
\text { test) }\end{array}$ & $\begin{array}{c}\text { Standard } \\
\text { Error }\end{array}$ & $P^{\prime}$ & $\begin{array}{c}\text { Partial } \\
\text { Eta } \\
\text { Square }\end{array}$ \\
\hline $\begin{array}{c}\text { Girls (pretest } \\
\text { and posttest) }\end{array}$ & $-14.22^{*}$ & .41 & .000 & .93 \\
\hline $\begin{array}{c}\text { Boys (pretest } \\
\text { and posttest) }\end{array}$ & $-12.72 *$ & .41 & .000 & .91 \\
\hline
\end{tabular}

* The difference between the averages is statistically significant. 'Bonferroni adjustment was made for comparisons.

A t-test was conducted for related samples to compare intra-group pre-test and post-test scores of girls and boys (Table 9). A statistically significant difference was found between the pretest scores and posttest scores of the girls ( $p$ $=.000, \eta 2=93)$ and the boys $(p=.000, \eta 2=91)$. In other words, academic success in both groups increased over time. The partial eta squares of intra-group differences indicate big effect size; however, the increase in girls' academic success is significantly higher than the increase in boys' academic success, as mentioned above. The 
diagram showing the variation of success scores by gender and time is given in Figure 2.

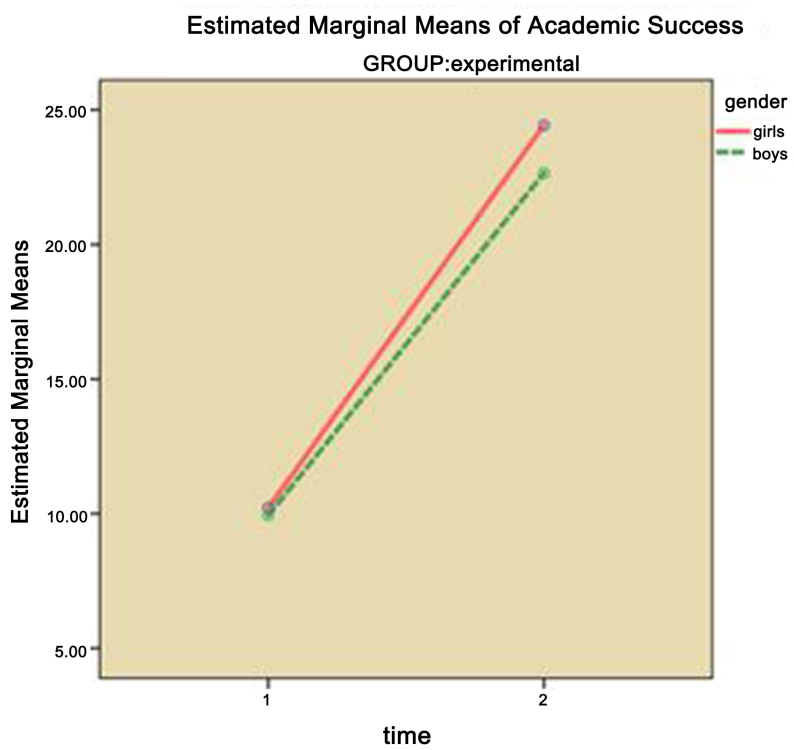

Figure 2. The change in academic success of male and female students over time.

\section{c) Effects of the Course Taught in Line with the Authentic Learning Activities by Socioeconomic Status}

Table 10. The mean and standard deviation values for the success scores of male and female students with different socioeconomic status (SES) in the experimental group

\begin{tabular}{|c|c|c|c|}
\hline Period of Time & $n$ & $M$ & $S D$ \\
\hline Pretest (low) & 30 & 10.00 & 1.39 \\
\hline Pretest (medium) & 31 & 10.10 & 1.47 \\
\hline Pretest (high) & 31 & 10.13 & 1.48 \\
\hline Posttest (low) & 30 & 23.10 & 2.11 \\
\hline Posttest (medium) & 31 & 24.29 & 3.26 \\
\hline Posttest (high) & 31 & 23.23 & 3.88 \\
\hline
\end{tabular}

The fifth research problem of the study focuses on whether the effect of the authentic learning activities-based teaching method on academic success varies by socioeconomic status of the students. To test this problem, mixed between-within variance analysis was performed using data of the students in the experimental group. While the academic success scores of the students constitute the dependent variable, the period of time when pre-test and post-test were conducted constitutes the first independent variable (time), and students' socioeconomic status (SES) of consisting of 3 categories (low, medium and high) constitutes second independent variable. Table 10 shows the scores and standard deviations that male and female students from the experimental group took from pre- and post-tests.
Table 11. Findings obtained from the mixed between-within variance analysis according to the socioeconomic status

\begin{tabular}{|l|l|l|l|l|}
\hline & Wilks' 'Lambda & $F(1,182)$ & $p$ & $\eta^{2}$ \\
\hline $\begin{array}{l}\text { Time-SES } \\
\text { interaction }\end{array}$ & .97 & 1.49 & .231 & .032 \\
\hline $\begin{array}{l}\text { Time } \\
\text { pretest, } \\
\text { posttest) }\end{array}$ & .042 & 2015.40 & $.000^{*}$ & .96 \\
\hline $\begin{array}{l}\text { SES (low, } \\
\text { medium, } \\
\text { high) }\end{array}$ & & .89 & .415 & .20 \\
\hline
\end{tabular}

*There is a statistically significant difference at the level of $\mathrm{p}<.01$.

The Levene test for posttest was found statistically significant $(\mathrm{p}=.032)$ in the analysis made. That is, the assumption of homogeneity of variances could not be ensured for the success scores in the post-test. For this reason, as suggested [34], the alpha value for the F test was taken as .01 rather than .05 , and the $p$ values obtained from the $\mathrm{F}$ tests were compared with.01. Findings from mixed between-within variance analysis (Table 11) showed that there was no significant interaction between socioeconomic status (SES) variable and time, Wilks' Lambda $=.97, F(2,89)=1.49, p=.231, \eta 2=.032$. On the other hand, the main effect testing the change over time was found statistically significant, Wilks' Lambda $=.042$, $\mathrm{F}(2,89)=2015.40, \mathrm{p}=.000, \eta 2=.958 . \mathrm{F}(2,89)=.89, \mathrm{p}$ $=.415, \eta 2=.020$. These findings show that the social studies course, based on authentic learning activities, has a similar effect on the academic success of students at all SES levels. The effect size of the differences between the groups indicates that only $2 \%$ of the variance of the academic success scores is explained by the SES variance. The diagram showing the change in academic success of SES groups over time is given in Figure 3.

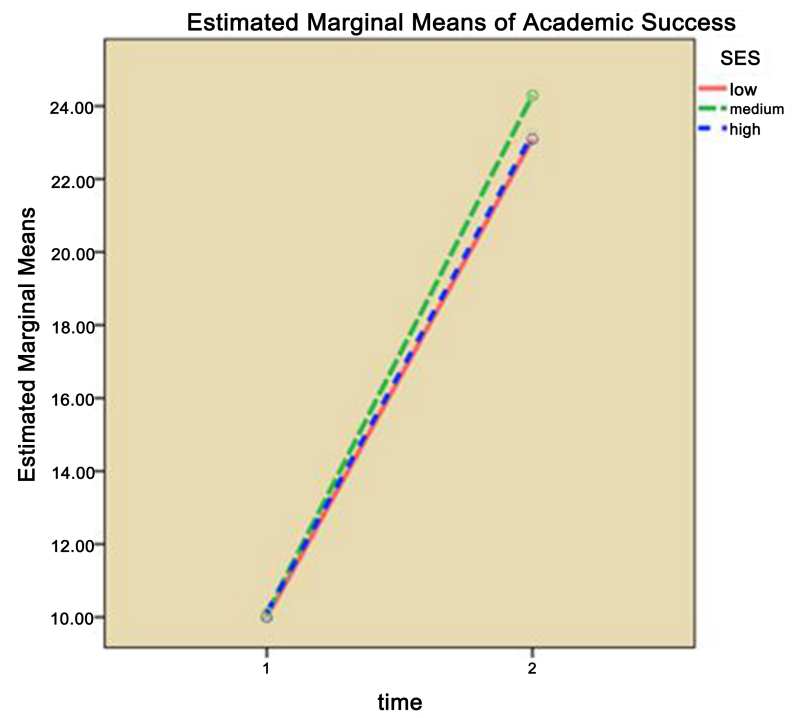

Figure 3. The change in the academic success of students from different socioeconomic status groups over time. 


\section{Conclusion, Discussion and Recommendations}

The purpose of this research is to reveal the effect of authentic learning activities prepared within the scope of the 5th grade social studies course 'Production, Distribution and Consumption' on the academic success of students. In the research, firstly the academic success results between experimental and control groups were compared. Accordingly, authentic learning activities regarding academic success were found to be more effective than the available programs. In the study conducted by Karakus [22], it has been concluded that authentic learning activities increased the academic success of the students. Likewise, in the study conducted by Hastürk [27], it has been concluded that authentic learning activities develop mental structure, contribute to significant learning and develop high-level skills. Similar results have also been found in other studies $[2,15,17,25$, 35]. In this context, it can be said that the results of the research overlap with the literature.

The second important result obtained in the research was obtained by comparing the academic success of the boy and girl students in the classrooms where authentic learning activities were carried out. Academic success that initially had similar characteristics in girls and boys has changed over time. At the end of the process, the increase in academic success of female students was higher than male students. The teaching materials prepared for authentic learning activities may be considered to be effective in formation of this situation. Because the gender of most of the characters in the WebQuest materials and script texts prepared for authentic learning activities is also female. It has also been observed that in the classroom girls are more willing to participate in the activities.

The third important result of the research is that authentic learning activities increase academic success in all socioeconomic statuses in a similar way. That is, socioeconomic status does not have a statistically significant effect on the authentic learning environment. Newmann \& Wehlage [35] in their research examined schools having different properties. As result of research it was obtained that authentic learning increases success in all schools at different socioeconomic status. The reason of encountering a similar result in both researches can be explained by taking part of students in this kind of study for the first time. It is thought that this research should be examined in other investigations. In addition, previous researches $[11,15,17,19,21,25,28,40]$ show that authentic learning activities influence students' attitudes positively and increase their success. According to Dilmaç and Dilmaç [19], the most important difference in authentic learning activities is that they give effective results in both successful and unsuccessful students. According to this finding, it can be said that authentic learning activities are effective in increasing academic success in all students regardless of socioeconomic status difference.
Unfamiliar and complex things for students can be taught to students with units associated with daily life and authentic learning activities. In the literature, it is emphasized that social studies and geography lessons fit the authentic learning concept and they should be used more in these lessons $[36,37]$. It is also stated in the literature that there are many methods, techniques, strategies and materials that teachers can use within the frame of authentic learning concept $[2,7,9,28,38]$. Herrington, Parker \& Boase-Jelinek [30] and McFarlane [7] says that authentic learning can be supported by information technology. Considering that nowadays, computers are thought to increase their effect in all areas of life, similar studies can be conducted with different materials prepared in computer environment, for different class levels.

As a result, this study shows that authentic learning activities increase students' success in the social studies course. In this study, the results of the lessons taught within the framework of authentic learning activities were determined by the academic success test. Authentic learning is an insight where alternative measurement and evaluation methods can be used [39]. In this context, it is also thought that it is also important to bring the literature in authentic learning activities to be determined by authentic evaluation tools.

\section{REFERENCES}

[1] Turkish Language Association (TDK). Online available from

http://www.tdk.gov.tr/index.php?option=com bts\&arama= kelime\&guid=TDK.GTS.5b7981 f587e428.93371548

[2] S. Koçyiğit, R. Zembat. Otantik görevlerin öğretmen adaylarının başarılarına etkisi. Hacettepe Üniversitesi Eğitim Fakültesi Dergisi, 28(3), 291-303, 2013a.

[3] F. M. Newman, G. G. Wehlage. Five standards of authentic instruction. Educational Leadership, 50(7), 8-12, 1993.

[4] J. E. Ormrod. Educational psychology: Developing learners. Upper Saddle River, NJ: Merrill, 2000.

[5] A. N. Knobloch. Is experiential learning authentic? Journal of Agricultural Education, 22(44), 22-34, 2003.

[6] J. Herrington, T.C. Reeves, R. Oliver. Authentic tasks online: A synergy among learner, task, and technology. Distance Education, 27(2), 233-247, DOI: 10.1080/01587910600789639. 2006.

[7] Z. F. İneç, E. Akpınar. Sosyal bilgilerin otantik öğretiminde yeni yaklaşımlar. Uluslararası Sosyal Alan Araştırmaları Dergisi, 6(2), 1-12, 2017.

[8] A. Gündoğan, M. Gültekin. Hayat bilgisi dersinde otantik görev temelli öğrenme ortamlarının oluşturulmasında yönelik örnek uygulamalar. Pegem Atıf İndeksi, 779-792. Doi:10.14527/9786053188407.55. 2017.

[9] M. M. Lombardi. Authentic learning for the 21st Century: 
An overview. ELI Report No 1. Boulder, Diana G. Oblinger (Ed.) In EDUCAUSE Learning Initiative, 2007.

[10] R. Gordon. A Curriculum for authentic learning. The Education Digest, 63(7), 4-8, 1998.

[11] M.B. Horzum, M. Bektaş. Otantik öğrenmenin topluma hizmet uygulamaları dersini alan öğretmen adaylarının derse yönelik tutum ve memnuniyetine etkisi. Kastamonu Eğitim Dergisi, 20(1), 341-360, 2012.

[12] M. Gürdoğan. Sınıf öğretmeni adaylarının otantik öğrenme yaklaşımının uygulanabilirliği ile ilgili görüşleri: fen ve teknoloji laboratuvar uygulaması örneği. Yayımlanmamış Yüksek Lisans Tezi Akdeniz Üniversitesi Eğitim Bilimleri Enstitüsü, Antalya, 2014.

[13] A. Herrington, J. Herrington. "What is an authentic learning environment?" In Authentic learning environments in higher education, Edited by: Herrington, A. and Herrington, J. Chapter I, 1-13. Hershey, PA: Information Science Publishing, 2006.

[14] S. Dolapçığlu-Doğan. Matematik dersinde otantik öğrenme yoluyla eleştirel düşünme becerisinin geliştirilmesi: bir eylem araştırması. Yayımlanmamış Doktora Tezi Çukurova Üniversitesi Sosyal Bilimler Enstitüsü, Adana, 2015.

[15] Z. Aşk-Aydın, E. Bay. 7. sınıf matematik dersinde otantik görev odaklı öğrenme süreçlerinin etkililiğinin değerlendirilmesi (eylem araştırması). Adnan Menderes Üniversitesi Eğitim Fakültesi Eğitim Bilimleri Dergisi, 9(1), 95-112, 2018.

[16] D. Melanlığlu. Impacts of authentic listening tasks upon listening anxiety and listening comprehension. Educational Research and Reviews, 8(14), 1177-1185, 2013.

[17] M. Güner, D. Ş. Belet-Boyacı. Türkçe dersinde dinlediğini anlama becerisinin geliştirilmesinde otantik görev temelli otantik materyallerin etkisi. Turkish Studies, 10(11), 757-772, 2015.

[18] N. Akça, B. Ata. Lise tarih derslerinde otantik etkinliklerin uygulanması ve sorunları. Eğitimde Yeni Yönelikler-V Öğrenmenin Doğası ve Değerlendirme Sempozyumu, İzmir, Türkiye, 390-400, 2009.

[19] S. Dilmaç, O. Dilmaç. Otantik değerlendirme yaklaşımlarının ortaöğretim öğrencilerinin görsel sanatlar dersine yönelik tutumlarına etkisi. Selçuk Üniversitesi Sosyal Bilimler Enstitüsü Dergisi, 32, 57-67, 2014.

[20] S. Azarmi. İngiliz dili eğitiminde otantik oyunların kullanımı. Yayımlanmamış Doktora Tezi Gazi Üniversitesi Eğitim Bilimleri Enstitüsü, Ankara, 2010.

[21] F. Karakuş. Sosyal bilgiler öğretiminde oluşturmacı öğrenme ve otantik değerlendirme yaklaşımlarının öğrencilerin sosyal bilgiler dersinde yönelik tutumlarına ve kalıcılığa etkisi. Çukurova Üniversitesi Eğitim Fakültesi Dergisi, 3(36), 124-141, 2009.

[22] F. Karakuş. Oluşturmacı öğrenme ve otantik değerlendirme yaklaşımlarının sosyal bilgiler öğretiminde ögrencilerin akademik başarı ve kalıcılığa etkisi. Çukurova Üniversitesi Sosyal Bilimler Enstitüsü Dergisi, 21(1), 101-116, 2012.

[23] S. Önger, T. Çetin. An investigation into digital literacy views of social studies preservice teachers in the context of authentic learning. Review of International Geographical Education Online, 8(1), 109-124, 2018.
[24] G. Scheurman, F. M. Newmann. Authentic intellectual work in social studies: Putting performance before pedagogy. Social Education, 62(1), 23-25, 1998.

[25] Z. F. İneç. Sosyal bilgiler dersinde geo-medya destekli otantik öğrenme ortamının öğrenmeye etkisi, Yayımlanmamış Doktora Tezi Erzincan Üniversitesi Sosyal Bilimler Enstitüsü, Erzincan, 2017.

[26] T. Valtonen, J. Kukkonen, S. Kontkanen, K. Sormunen, P. Dillon, E. Sointu. The impact of authentic learning experiences with ICT on pre-service teachers' intentions to use ICT for teaching and learning, Computers \& Education, 81, 49-58, 2014.

[27] G. H. Hastürk. Öğretmen adaylarının bazı çevre konularına ilișkin zihinsel yapılarındaki değişimlerin otantik öğrenme ortamlarında incelenmesi ve değerlendirilmesi. Yayımlanmamış Doktora Tezi Gazi Üniversitesi Eğitim Bilimleri Enstitüsü, Ankara, 2013.

[28] S. Koçyiğit, R. Zembat. Otantik görevlerin öğretmen adaylarının derse karşı tutumlarına ve problem çözme becerilerine etkisi. Kuram ve Uygulamada Eğitim Bilimleri, 13(2), 1027-1051, 2013b.

[29] İ. Kinay, B. Bağçeci. Otantik değerlendirme yaklaşımının öğretmen adaylarının öğrenmeye ve katılımcı değerlendirmeye yönelik inançlarına etkisinin incelenmesi. Dumlupınar Üniversitesi Sosyal Bilimler Dergisi, 52, 16-32, 2017.

[30] J. Herrington, J Parker, D. Boase-Jelinek. Connected authentic learning: Reflection and intentional learning. Australian Journal of Education, 58(1), 23-35, 2014.

[31] S. Çepni. Araştırma ve Proje Çalışmalarına Giriş (7. Baskı), Celepler Matbaacılık, Trabzon, 2014.

[32] N. Karasar. Bilimsel Araştırma Yöntemi, Nobel Akademik Yayıncılık Eğitim Danışmanlık, Ankara, 2012.

[33] J. Cohen. Statistical power analysis for the behavioral sciences, (2nd Ed). Hillsdale, NJ: Lawnence Erlbaum Associates, 1988.

[34] J. Pallant. SPSS survival manual. McGraw-Hill Education (UK), 2013.

[35] F. M. Newmann, G. G. Wehlage. Successful school restructuring. Madison, Center on Organization and Restructuring of Schools, School of Education, University of Wisconsin-Madison, 1995.

[36] H. Kazanci. Otantik öğrenme açısından yerel coğrafi bilgi (Artova örneği). Yayımlanmamış Yüksek Lisans Tezi Gaziosmanpaşa Üniversitesi Sosyal Bilimler Enstitüsü, Tokat, 2010.

[37] G. Alacahan. Otantik öğrenmede yerel coğrafi bilgi ve halk takvimi. Adnan Menderes Üniversitesi Sosyal Bilimler Enstitüsü, Aydın, 2016.

[38] M. Bektaş, B. M. Horzum. Otantik öğrenme, Pegem Akademi Yayıncılık, Ankara, 2014.

[39] A. Doğanay. Çağdaş sosyal bilgiler anlayışı ışı̆̆ında yeni sosyal bilgiler programının değerlendirilmesi. Çukurova üniversitesi Sosyal Bilimler Enstitüsü Dergisi, 17(2), 77-96, 2008.

M. Gürdoğan, A. Aslan. Sınıf öğretmeni adaylarının otantik öğrenme yaklaşımı hakkındaki görüşleri. Fen Bilimleri Öğretimi Dergisi, 4(2), 114-140, 2016. 